\title{
ASSESS THE EFFECTIVENESS OF STRUCTURED TEACHING PROGRAMME ON KNOWLEDGE REGARDING DENGUE FEVER AMONG HIGH SCHOOL CHILDREN.
}

\section{Mrs.Nutan \\ Mrs.Gurpreet Kaur*}

\section{Dr.Parampal Kaur} Cheema
Associate Professor, Swami Premanand College of Nursing,Mukerian Assistant Professor,Swami Premanand College of Nursing,Mukerian. ${ }^{*}$ Corresponding Author

\section{ABSTRACT}

Disease is any harmful deviation from the normal structural or functional state of an organism, generally associated with certain signs and symptoms. One of the most important tropical infectious disease is dengue. Dengue fever is commonly known as 'Break Bone Fever'. It is an infectious disease caused by a virus Arbovirus from the genus Flavivirus. It is transmitted by mosquito, Aedes aegypti closely associated with human habitation. Dengue fever is caused by four antigenically related but distinct dengue virus transmitted by infected mosquitoes.

\section{KEYWORDS : Effectiveness, dengue fever and high school children.}

\section{INTRODUCTION}

Dengue is an infectious disease caused by a virus Aedes Aegypti. Dengue causes severe flu-like symptoms such as a high temperature of 40 degree Celsius or 104 degree Fahrenheit or over, server headache, muscle and joint pain, facial flushing and skin rash. Anyone can catch dengue if the disease is common in the endemic area. However dengue is more common among older children, adolescent and adults. Dengue is self-limiting disease. The word Self-limiting means that it clears up by itself, usually within a couple of weeks. The incubation period for dengue is 5-8 days. More than 50100 million cases occurred as worldwide incidence and more than 14,233 cases found in India and 20,000 deaths occurred in India. About 2500 cases of dengue fever are identified in Punjab.

\section{STATEMENT OF THE PROBLEM}

A pre-experimental study to assess the effectiveness of structured teaching programme on knowledge regarding dengue fever among high school children of Mukerian, District Hoshiarpur, Punjab.

\section{OBJECTIVES}

- To assess the pre-test level of knowledge regarding dengue fever among high school children.

- To assess the post-test level of knowledge regarding dengue fever among high school children.

- To compare the pre-test and post-test knowledge regarding dengue fever among high school children.

- To find out the relationship between the pre-test and posttest knowledge regarding dengue fever among high school children with selected demographic variables.

\section{REVIEW OF LITERATURE}

A Descriptive study was conducted to assess the clinical features of dengue virus among 200 infected pediatric patients admitted in hospitals of West Bengal and Bihar. A direct history and clinical examination record based technique is used. The result revealed that about $63 \%$ children had myalgia and arthralgia, $28 \%$ has GI infections , $55.5 \%$ had headache, $25.5 \%$ had rash and $13 \%$ had hemorrhagic manifestations. Features of shock were present in $7 \%$ children, retro-orbital pain in $6.5 \%$ children and generalized swelling in $4.5 \%$ children. The result concluded that increased awareness about changing clinical features of dengue in pediatric cases as observed in recent epidemics is needed to further reduce mortality and complications of dengue cases. (Banerjee $\bar{A}$ ,2018)

A cross-sectional study was carried out to assess the knowledge, attitude and practice of dengue fever among high school children in Villupuram municipality of Villupuram. Multi stage sampling and questionnaire was used to collect the data. The required information obtain by means of validated questionnaire. The result revealed that more than $75 \%$ has good knowledge on breeding source of infection $50 \%$ were not aware about breeding source of infection. More than half of them were attitude that they are not at a risk of dengue fever $59 \%$ of the respondent felt they were scared if they were to be infected. This study concluded that school students had adequate basics knowledge regarding dengue. There were some misconceptions regarding dengue. The study concluded that personal protection and trash removal was last Practice which can be made successful by behavior change communication. (Sasikaladevi S. Kandaswamy's EK 2018)

\section{RESEARCH METHODOLOGY}

A Quantitative approach was adopted to accomplish the objectives of the study to evaluate the effectiveness of structured teaching programme on knowledge regarding dengue fever among High School Children at Mukerian, Hoshiarpur Punjab. It consists of knowledge questionnaire to evaluate the knowledge of high school children regarding dengue fever. A self-administered questionnaire was used to elicit the information, which include two parts: l.demographic variables 2. Self Structured Knowledge Questionnaire consists of 20 items of multiple choice questions to evaluate the knowledge regarding dengue fever among high school children. The data analysis was done by calculating frequency, percentage, mean, standard deviation, ' $t$ ' test and Ftest.

\section{RESULTS:}

The results of present study revealed that $20 \%$ school children had poor knowledge and 35\% had average knowledge and $45 \%$ of them had good knowledge score during pretest regarding dengue fever. The findings of post test revealed that $50 \%$ school children had good knowledge and $50 \%$ had average knowledge and none of them had poor knowledge.

Table: Comparison of mean pre-test and post-test knowledge score of high school children regarding dengue fever to find out the effectiveness of structured teaching programme.

\begin{tabular}{|l|l|l|l|l|l|l|l|}
\hline \multicolumn{9}{|c}{ Knowledge score } & $\mathrm{N}=40$ \\
\hline & Mean & SD & MEAN & SD & $\begin{array}{l}\text { Mean } \\
\text { difference }\end{array}$ & $\mathrm{t}$ & df \\
\hline Pre-test & 9.85 & 5.803 & 12.575 & 2.94 & 2.725 & 6.013 & 78 \\
\hline $\begin{array}{l}\text { Dengue fever } \\
\text { score }\end{array}$ & & & & & & & \\
\hline
\end{tabular}


It depicts that the mean pre-test and mean post-test score of high school children regarding dengue fever were 9.85 and 12.575 respectively. The difference between the mean pre-test and mean post-test score was 2.725 and the calculated 't' value was 6.013 which was statistically significant at $p<0.05$ level. Hence, the research hypothesis $\mathrm{Hl}$ was accepted.

Thus it can be concluded that, structured teaching programme was an effective tool in improving the knowledge of high school children regarding dengue fever. The findings of pre-test study revealed that age, gender, standard, family income, parental education, source of information had no significant relationship with pre-test and post-test knowledge regarding dengue fever of high school children.

\section{DISCUSSION}

In this chapter, an attempt has been made to discuss the findings in the study in accordance with the objectives of the research. The investigator interpretatively discuss the result of the study in the discussion. The study was, A pre-experimental study to assess the effectiveness of structured teaching programme on knowledge regarding dengue fever among high school children of Mukerian, District Hoshiarpur, Punjab. The findings of present study revealed that $20 \%$ school children had poor knowledge and $35 \%$ had average knowledge and $45 \%$ of them had good knowledge score during pretest regarding dengue fever. Similar findings were reported by (Ibrahim NK et al, 2009) that pre-test knowledge score was poor, fair and satisfactory for $42.3 \%, 57.6 \%$ and $0.1 \%$ of total sample. These findings of post test study revealed that $50 \%$ school children had good knowledge and $50 \%$ had average knowledge and none of them had poor knowledge regarding dengue fever.Similar findings were reported from (Mohammed Faez Baobaid, et al 2015) that $63.2 \%$ students had good knowledge while $36.8 \%$ students had moderated to poor knowledge about dengue fever.

\section{SUMMARY and CONCLUSION}

The present study was conducted as an attempt to evaluate the effectiveness of structured teaching programme in improving knowledge regarding dengue fever among high school children in selected schools of Mukerian. The difference between mean pre-test \& post-test knowledge score was statistically significant at $p<0.005$ level. Thus, structured teaching programme was an effective tool in improving the knowledge of high school children regarding dengue fever.The findings of pre-test study revealed that age, gender, standard, family income, parental education, source of information had no significant relationship with pre-test and post-test knowledge regarding dengue fever of high school children.

\section{REFERENCES}

1. Amar T. Dengue fever and severe Dengue .March 2014.Retrieved from http;www.who.int \\Median centre abnd facts sheets \fs 1 17〉en\.

2. Rahman M, Rahman M, Rahman K, Siddque AK, Shoma S, kamal AH,etal. First outbreak of dengue hemorrhagic fever,Bangaladesh Emerg infect Dis 2002;8;738-40

3. Park K.Parks Textbook of Preventive and Social Medicine .23rd ed.Jabalpur:Banarasidas Bhanot Publishers . 2015

4. WHO.Media Centre Fact Sheet,Dengue and Dengue hemorrhagic fever.updated April 2017.Available at ;http;//www.who.int/Accessed on 3August 2017.

5. Sasikaladevi S. Kandaswamy's EK. cross sectional study on knowledge, attitude and practice of dengue fever among high school students. International Journal of Community Medicine and Public Health 5(2) January 2018 DOI: 10.18203/2394-.6040.ijcmph20180116.

6. Banerjee A, Barik KL , Bandyopadhyay A , Paul U K. A study on the clinical features of dengue virus infected pediatric patients. International Journal of Contemporary Pediatrics.2018. DOI: http://dx.doi.org/10.18203/23493291.ijcp20180437.Available from: https:// www. ijpediatrics. com/index. php/ ijcp/article/view File/1421/1021 